Ritrýnd grein birt 11. júní 2019

\title{
Heterósexísk orðanotkun íslenskra framhaldsskólanema
}

\author{
Aðalbjörg Eva Aðalsteinsdóttir og Jón Ingvar Kjaran
}

\begin{abstract}
Um höfundana $\quad$ About the authors Heimildir
Rannsóknin fjallar um heterósexíska orðanotkun íslenskra framhaldsskólanemenda sem hefur ýmsar birtingarmyndir. Erlendar rannsóknir benda til að orðanotkunin valdi nemendum ópægindum en fáar íslenskar rannsóknir fjalla um efnið. Markmiðið var að skoða tilteknar íslenskar birtingarmyndir orðanotkunarinnar, svo sem notkun orðanna faggi/faggalegt um óviðeigandi hegðun og gay um heimskulega/asnalega hegðun/fyrirbæri. Algengi orðanotkunarinnar var skoðað, kynjamunur, aðstæðurnar sem orðanotkunin fór fram í innan skóla, á netinu og annars staðar samanborið við utan skóla og áhrif orðalagsins á líðan nemenda. Gagna var aflað með spurningalista sem var lagður fyrir nemendur 18 ára og eldri $(\mathrm{n}=149)$ í premur framhaldsskólum með bekkja- eða áfangakerfi á höfuðborgarsvæðinu. Algengi orðanotkunarinnar var misjafnt, transa/tranný yfir trans fólk var sjaldgæfast (5\%) en faggi/faggalegt yfir óviðeigandi hegðun var algengast (54\%) og pví næst kynskiptingur yfir trans fólk (34\%). Strákar voru líklegri en stelpur til að hafa notað sum form heterósexísks orðalags. Hærra hlutfall pátttakenda taldi að peir væru líklegri til að nota heterósexískt orðalag utan skóla en í búningsklefanum, í ípróttatíma eða í skólastofum. Hlutfall pátttakenda sem upplifði ópægindi af að heyra orðanotkunina var misjafnt. Hæst hlutfall pátttakenda upplifði ópægindi af að heyra trukkalessa um stelpu sem hegðaði sér ekki kvenlega (65\%), 64\% upplifðu ópægindi af að heyra gay yfir heimskulega/asnalega hegðun og $63 \%$ af að heyra faggi yfir strák sem hegðaði sér ekki karlmannlega. Fæstir pátttakendur upplifðu ópægindi af að heyra orðið kynskiptingur um trans fólk (32\%). Niðurstöður rannsóknarinnar benda til að íslenskir framhaldsskólanemendur noti heterósexískt orðalag í mismiklum mæli en margir upplifi ópægindi af að heyra pað. Ef hægt er að draga úr slíku orðalagi gæti pað haft jákvæð áhrifá nemendur í námi og í framtíðinni.
\end{abstract}

Efnisord: Heterósexísk orðanotkun, heterósexismi, hómófóbía, hið gagnkynhneigða regluveldi, kyngervi, framhaldsskólanemendur.

\section{Inngangur}

Erlendar rannsóknir hafa staðfest heterósexíska orðanotkun innan skólakerfa. Ein af birtingarmyndum orðanotkunarinnar er hómófóbía (e. homophobia) og hroki eða hatur gagnvart trans fólki (Kosciw, Greytak, Giga, Villenas og Danischewski, 2016; Pascoe, 2005; Payne, 2007; Taylor o.f1., 2011). Slík orðanotkun getur valdið öllum nemendum ópægindum hvort sem peir eru hinsegin (samkynhneigðir, tvíkynhneigðir, trans fólk eða skilgreina kyngervi sitt eða kynhneigð í andstöðu við ríkjandi viðmið) eða ekki (Kosciw o.fl., 2016; Taylor o.fl., 2011). Í Aðalnámskrá framhaldsskóla (Mennta- og menningarmálaráðuneytið, 2012) er fjallað 
um grunnpáttinn „Jafnrétti“ sem kveður á um að nemendur skuli læra um jafnrétti í víðum skilningi. Í pví felst að greina forréttindi og mismunun ásamt ólíkum páttum sem geta orsakað mismunun sumra hópa og forréttindastöðu annarra. Meðal pátta sem tilgreindir eru í Aðalnámskrá framhaldsskóla og geta mögulega aukið líkur á mismunun eru kyn og kynhneigð (Menntaog menningarmálaráðuneytið, 2012). Segja má að hvers kyns heterósexísk orðanotkun geti ýtt undir pess háttar mismunun pví orðanotkunin styður við heterósexisma sem gerir ráð fyrir að gagnkynhneigð sé ríkjandi viðmið og öðrum kynhneigðum pví gefið minna vægi (Herek, 2000; Pharr, 1988). Í Aðalnámskrá framhaldsskóla (Mennta- og menningarmálaráđuneytið, 2012) kemur fram að meðal peirra pátta sem nemendur eigi að hljóta pjálfun í séu samskipti við aðra par sem jafnrétti og mannréttindi eru lykilatriði. Heterósexísk orðanotkun framhaldsskólanemenda samræmist pví ekki Aðalnámskrá framhaldsskóla (Mennta- og menningarmálaráđuneytið, 2012).

Fáar íslenskar rannsóknir fjalla um stöðu hinsegin nemenda (sjá pó Jón Ingvar Kjaran og Ingólf Ásgeir Jóhannesson, 2010; Jón Ingvar Kjaran og Ingólf Ásgeir Jóhannesson, 2011) og nær engar hafa skoðað algengi heterósexísks orðalags meðal nemenda í framhaldsskólum. Rannsókn Jóns Ingvars Kjarans (2016) skoðar pó kynjamun sambærilegrar orðanotkunar en par kom fram að strákar voru líklegri en stelpur til að nota orð á borð við faggalegt yfir mynd af tveimur strákum að kyssast eða mynd af strák sem uppfyllti ekki viðmið um karlmannlegt útlit.

Hér verður gerð grein fyrir niðurstöðum rannsóknar á algengi heterósexískrar orðanotkunar í íslenskum framhaldsskólum. Heterósexísk orðanotkun getur verið mismunandi og hefur margar birtingarmyndir, ekki er hægt að lýsa peim öllum í pessari rannsókn og pví einblínt á tiltekin form hennar eins og notkun neikvæðra orða yfir hinsegin einstaklinga, hvort sem pað er meðvitað eða ómeðvitað, pó orðanotkunin beinist ekki endilega að peim. Hlutlaus orð sem notuð eru til að lýsa kynhneigð gætu einnig verið tekin úr samhengi og notuð í neikvæðri merkingu, meðvitað eða ómeðvitað.

Til að skilgreina heterósexíska orðanotkun var stuðst við erlendar og íslenskar rannsóknir ásamt öðrum heimildum (Guasp, Statham, Jadva og Daly, 2012; Kosciw o.fl., 2016; Pascoe, 2005; Payne, 2007; Jón Ingvar Kjaran og Ingólfur Ásgeir Jóhannesson, 2011; Slangurordabókin, 2011; Trans Ísland, e.d.-a). Hafa skal í huga að heterósexískt orðalag á ensku hefur ekki endilega sömu merkingu í íslenskri pýðingu vegna menningarbundins munar. Pví er ekki sjálfgefið að orðanotkun á Íslandi sé sú sama.

Hér á eftir fylgir skilgreining rannsóknarinnar á heterósexísku orðalagi sem skoðað var og peim heimildum sem stuðst var við pegar hvert form orðanotkunarinnar var skilgreint:

- Notkun orðsins gay til að lýsa pví að hlutur/fyrirbæri sé heimskulegt eða asnalegt líkt og lýst var í niðurstöðum rannsókna Pascoe (2005) og Kosciw o.fl. (2016).

- Notkun orðsins gay um heimskulega/asnalega hegðun líkt og í niðurstöðum rannsóknar Kosciw o.fl. (2016).

- Notkun frasans no homo til að ítreka gagnkynhneigð eins og í niðurstöðum rannsóknar Kosciw o.fl. (2016).

- Notkun orðsins faggi yfir strák sem hegðar sér ekki karlmannlega en Pascoe (2005) lýsti viðlíka orðanotkun par sem enska orðið fag var notað. Niðurstöður rannsóknar Jóns Ingvars Kjarans og Ingólfs Ásgeirs Jóhannessonar (2011) bentu til að orðið faggi væri notað á Íslandi.

- Notkun orðanna faggi/faggalegt yfir hegðun sem pátttakendum líkar ekki, faggi getur verið hluti af orði og dæmi um slíkt orð er karustufaggi. Dæmi um notkun lýsingarorðsins faggalegt er að finna í niðurstöðum rannsóknar Jóns Ingvars Kjarans (2016). Slangurorðabókin (2011) skilgreindi orðið karustufaggi sem strák sem eyðir miklum tíma með kærustu sinni á kostnað vina. Hins vegar virðist orðið einnig nothæft yfir önnur kyn.

- Notkun orðsins lessa yfir stelpu sem hegðar sér ekki kvenlega og gæti verið pýðing á uppnefninu lezza líkt og kom fram í niðurstöðum rannsóknar Guasp o.fl. (2012). 
Íslenska orðið lessa getur einnig verið hlutlaust orð, notað til að lýsa kynhneigð sem væri í samræmi við bróun á notkun orðanna hommi og lesbía sem höfðu áđur neikvæða merkingu en urðu loks hlutlaus (Póra Björk Hjartardóttir, 2005). Með heterósexískri notkun er merking orðsins pví tekin úr samhengi par sem pað lýsir ekki lengur kynhneigð en er í staðinn notað með neikvæðum hætti.

- Notkun orðsins trukkalessa yfir stelpu sem hegðar sér ekki kvenlega og gæti verið möguleg pýðing af uppnefninu dyke líkt og lýst var í niðurstöðum rannsóknar Kosciw o.fl. (2016) og Payne (2007).

- Notkun orðsins kynskiptingur um trans fólk. Orðið pykir óviðeigandi pví pað pykir hafa neikvæða merkingu nú til dags (Trans Ísland, e.d.-a).

- Notkun uppnefnanna transa/tranný um trans fólk en orðin gæu verið pýðing á uppnefninu tranny sem finna má í niðurstöðum rannsóknar Kosciw o.fl. (2016). Óvíst er hversu algeng slík orðanotkun er pví félagið Trans Ísland var ekki stofnað fyrr en 2007 (Trans Ísland, e.d.-b) og pví mögulega minni meðvitund um að ósamræmis geti gæett milli kyns og kyngervis fólks. Dví er hugsanlegt að önnur uppnefni/orð en transa/tranný séu notuð eins og orðið kynskiptingur. Spurt var um orðin transa/tranný engu að síður til að athuga hvort pau væru notuð.

Greinin byggir á niðurstöðum rannsóknar sem gerð var fyrir meistararitgerð fyrri höfundarins við Háskóla Íslands. Tilgangur rannsóknarinnar var að skoða heterósexíska orðanotkun meðal íslenskra framhaldsskólanema. Markmiðin voru að kanna algengi orðanotkunarinnar, áhrif kyngervis á orðanotkunina, áhrif hennar á nemendur og hversu líklegir pátttakendur voru til að nota orðalagið í ólíkum aðstæðum innan skólans, á netinu og annars staðar samanborið við utan skólans.

\section{Rannsóknarspurningarnar voru fjórar:}

1. Hversu algeng er heterósexísk orðanotkun meðal íslenskra framhaldsskólanema?

2. Hver eru áhrif kyngervis á orðanotkunina?

3. Eru íslenskir framhaldsskólanemendur jafn líklegir til að nota orðalagið í mismunandi aðstæðum innan skóla, á netinu og annars staðar samanborið við utan skóla?

4. Hver eru áhrif heterósexísks orðalags á íslenska framhaldsskólanemendur?

\section{Fræðilegur rammi}

\section{Hugtök}

Heterósexismi (e. heterosexism) felur í sér pá ályktun að allt fólk sé gagnkynhneigt (Jackson, 2006; Pharr, 1988). Degar gert er rád fyrir að allir séu gagnkynhneigðir verður sú kynhneigð að viðmiði og forréttindum gagnkynhneigðra pannig viðhaldið pví hún er talin hafa meira vægi en aðrar kynhneigðir líkt og samkynhneigð og tvíkynhneigð (Herek, 2000; Pharr, 1988).

Hið gagnkynhneigða regluveldi (e. heteronormativity) og heterósexismi eru skyld hugtök (Jón Ingvar Kjaran og Ingólfur Ásgeir Jóhannesson, 2010). Hið gagnkynhneigða regluveldi styður gagnkynhneigða menningu (Donelson og Rogers, 2004; Warner, 1993) og skyldubundna gagnkynhneigð (Jackson, 2006; Rich, 1980) sem felst í stofnanabindingu gagnkynhneigðar. Dví pykir gagnkynhneigð eðlileg (Jackson, 2006) og gert er ráð fyrir að flestir tileinki sér hana (Rich, 1980). Einnig byggir hið gagnkynhneigða regluveldi á eðlishyggju og tvíhyggjuhugmyndum um kyn/kyngervi (Butler, 1990; Connell, 2005; Eckert, 1989; Gentile, 1993; Jackson, 2006). Deir sem á einhvern hátt falla utan tvíhyggjunnar eru jaðarsettir og mæta skilningsleysi (Butler, 1990) enda gert ráð fyrir að viðmið kyngervis/kynhneigðar samræmist pví sem Butler (1990) nefnir hið gagnkynhneigða form (e. heterosexual matrix). 
Herek (2000) leggur til aðgreiningu á hugtökunum hómófóbíu og heterósexisma. Hann telur hugtakið hómófóbíu heppilegra til að lýsa neikvæðum einstaklingsbundnum viðhorfum til samkynhneigðra eða fordómafullri hegðun. Hugtakið heterósexismi er heppilegra til að lýsa samfélagslegum gildum og birtist pað í stofnunum samfélagsins sem og tungumálinu (Herek, 2004).

Hugtökin bífóbía (e. biphobia) og transfóbía (e. transphobia) eru skyld hómófóbíu. Bífóbía felst í að tvíkynhneigðir mæti skilningsleysi á pví að laðast að körlum og konum (Bennett, 1992). Transfóbía felst í að eigna trans fólki neikvæða ímynd og að mismuna peim (Sugano, Nemoto og Operario, 2006). Samkvæmt heimasíðu Trans Ísland (e.d.-c) er hugtakið trans (e. transgender) notað sem regnhlífarhugtak yfir ólíka hópa sem upplifa að kyngervi, -tjáning og -vitund samræmist ekki kyni sem skilgreint er út frá líffræðilegum og pannig líkamlegum viðmiðum (Gentile, 1993). Hugtakið sís eða sískynja (e. cis, cisgender) er notað til að lýsa einstaklingum sem upplifa að samræmi sé milli kyns peirra og kyngervis, -vitundar og -tjáningar (Aultman, 2014). Sískynja einstaklingar eru peir sem teljast „eðlilegir“ innan hins gagnkynhneigða forms samkvæmt Butler (1990).

\section{Stutt yfirlit um rannsóknir á sviðinu}

Rannsóknir hafa lýst ýmsum birtingarmyndum hins gagnkynhneigða regluveldis, heterósexisma og hómófóbíu í enskumælandi löndum (Burn, 2000; Guasp o.fl., 2012; Kosciw o.fl., 2016; Nayak og Kehily, 1996; Pascoe, 2005; Payne, 2007; Taylor o.fl., 2011), innan Evrópu (Collier, Bos og Sandfort, 2013; Slaatten, Anderssen og Hetland, 2014; Slaatten og Gabrys, 2014; Weber og Gredig, 2018) og á Íslandi (Jón Ingvar Kjaran og Ingólfur Ásgeir Jóhannesson, 2010; Jón Ingvar Kjaran og Ingólfur Ásgeir Jóhannesson, 2011; Jón Ingvar Kjaran, 2016). Birtingarmyndirnar felast til dæmis í notkun orða eins og fag/faggot, dyke, lezza, faggi og trukkur en pó hægt sé að pýða ensku orðin yfir á íslensku pýðir pað ekki að pau haldi merkingu sinni. Einnig er óvíst að íslensku orðin hafi sömu menningarbundnu merkingu og pau ensku. Dví voru ensku orðin notuð í umfjöllun um rannsóknir sem ritaðar voru á ensku og íslensku orðin í umfjöllun um rannsóknir sem ritaðar voru á íslensku.

Umfjöllunarefni rannsóknar Nayak og Kehily (1996) var hvernig strákar í breskum framhaldsskóla sýndu hómófóbíu með ýmsu móti og hvernig hún mótaði karlmennsku peirra. Meðal birtingarmynda hómófóbíu var notkun orðsins gay sem skammaryrði yfir stráka sem sýndu ekki æskilega (karlmannlega) hegðun.

Merking orðsins gay var önnurí niðurstöðum rannsóknar Pascoe (2005) sem var gerðíbandarískum framhaldsskóla. Par notuðu strákar og stelpur orðið yfir eitthvað sem pótti heimskulegt. Notkun pátttakenda í rannsókn Pascoe (2005) á orðinu gæti pví virst lýsa minni hómófóbíu en notkun pátttakenda í rannsókn Nayak og Kehily (1996). Niðurstöður rannsóknar Nicolas og Skinner (2012) sem gerð var í bandarískum háskóla sýndi að álíka notkun á orðinu gay og Pascoe (2005) lýsti hafði neikvæð áhrif. Einstaklingar sem heyrðu gay notað á neikvæðan hátt voru líklegri til að tileinka sér óbein neikvæð viðhorf til samkynhneigðra (Nicolas og Skinner, 2012). Neikvæð og niðrandi notkun orðsins gay hefur einnig átt sér stað í grunnskóla líkt og fram kom í niðurstöðum rannsóknar Renold (2005) sem gerð var í tveimur breskum grunnskólum.

Rannsókn Pascoe (2005) skoðaði fyrirbæri sem höfundur nefndi fagga-orðræðuna (e. fagdiscourse) en niðurstöðurnar bentu til að hún mótaði karlmennsku stráka og minnti pá á að sýna hana. Orðinu fag (faggi) var pá beint að strákum sem á einhvern hátt fylgdu ekki ríkjandi viðmiðum um karlmennsku, meðal annars pví peir sýndu veikleika sína og/eða peir póttu kvenlegir. Í rannsókn Pascoe (2005) var orðið fag aldrei notað yfir stelpur og sjaldgæft að pær notuðu pað í samskiptum sín á milli eða við aðra. Jafnframt bentu niðurstöðurnar til að orðin dyke (lessa, trukkur, trukkalessa) og lesbian (lessa, lesbía) væru ekki notuð um stelpur í sama tilgangi (Pascoe, 2005). 
Hómófóbísk eða heterósexísk orðanotkun getur pó einnig beinst að stelpum. Niðurstöður rannsóknar Guasp o.fl. (2012) sem gerð var í Bretlandi sýndu að orðið lezza (lessa, lesbía) var meðal annars notað sem hómófóbískt uppnefni. Niðurstöður rannsóknar Payne (2007), sem var framkvæmd í bandarískum framhaldsskóla, bentu til að orðin faggot (faggi) og dyke væru notuð sem uppnefni yfir samkynhneigðar stelpur. Pátttakendur rannsóknarinnar upplifðu jafnframt önnur form heterósexisma og hómófóbíu, svo sem að pær pyrftu að uppfylla útlitsskilyrði til að geta verið vinsælar, eins og að vera grannar og nota farða (Payne, 2007).

Niðurstöður rannsóknar Burn (2000) sem gerð var í bandarískum háskóla bentu einnig til að uppnefni eins og fag hefðu verið notuð meðal bandarískra háskólanema og að strákar notuðu orðalagið frekar en stelpur. Strákar heyrðu auk pess orðalagið oftar og höfðu frekar neikvæð viðhorf til samkynhneigðra. Fylgni milli viðhorfa og notkunar neikvæðra orða yfir samkynhneigða var marktæk en skýrði pó eingöngu 29\% fylgninnar. Möguleg skýring var talin felast í að slík orðanotkun mótaði karlmennsku stráka í skólanum og að peir sem ekki höfðu neikvæð viðhorf til samkynhneigðra en notuðu orðalagið gerðu pað til að aðlagast hópnum (Burn, 2000).

Loks skal tekið fram að heterósexísku orðalagi parf ekki að vera beint sérstaklega að einstaklingum vegna kynhneigðar peirra. Sumir pátttakendur í rannsókn Pascoe (2005) tóku fram að peir notuðu ekki orðið fag yfir samkynhneigða einstaklinga pó álíkt orðalag hefði vissulega verið notað til að móta karlmennsku stráka (sjá til dæmis Pascoe, 2005; Nayak og Kehily, 1996).

Í Bandaríkjunum hafa samtökin Gay, Lesbian and Straight Education Network (GLSEN) kannað skólabrag og menningu. Samtökin notuðust við spurningalista við könnunina og athuguðu meðal annars hversu oft hinsegin (samkynhneigðir, tvíkynhneigðir og trans) nemendur á grunnskólaog framhaldsskólaaldri (meðalaldur 16,1 árs) heyrðu neikvæða notkun orðsins gay, frasann no homo til að ítreka gagnkynhneigð eða önnur uppnefni sem einkennast af hómófóbíu. Pá er átt við uppnefni eins og fag eða dyke, tranny (transa/tranný) og he/she (hann/hún). Hversu oft pátttakendur urðu varir við hvert form orðanotkunarinnar var misjafnt. Hæst hlutfall hinsegin nemenda (um 67\%) heyrði gay notað í neikvæðri merkingu oft eða mjög oft en rúmlega helmingur (um 59\%) heyrði fag og dyke notað oft eða mjög oft. Tæplega helmingur $(40,5 \%)$ hinsegin nemenda heyrði uppnefnin tranny og he/she oft eða mjög oft en lægst hlutfall (um 39\%) heyrði frasann no homo oft eða mjög oft. Nánast allir (um 94\%) hinsegin nemenda sem urðu varir við neikvæða notkun orðsins gay og frasann no homo upplifðu einhver ópægindi (Kosciw o.fl., 2016; Kosciw, Greytak, Bartkiewicz, Boesen og Palmer, 2012).

Skólabragur kanadískra skóla hefur einnig verið kannaður og upplifun nemenda (meðalaldur 17,4 ára), sem voru gagnkynhneigðir eða hinsegin (samkynhneigðir, tvíkynhneigðir, transgender, transsexual, two-spirited, hinsegin og óvissir), skoðuð með spurningakönnun. Pátttakendur voru meðal annars beðnir að meta algengi pess að heyra neikvæða notkun orðsins gay, uppnefnin faggot, lezbo (lessa, trukkur, trukkalessa), dyke og queer ásamt áhrifum pess að heyra orðanotkunina. Meirihluti pátttakenda (um 70\%) heyrði gay notað daglega í neikvæðri merkingu en 47,5\% heyrði uppnefnin faggot, lezbo, dyke og queer daglega. Tæplega 60\% gagnkynhneigðra pátttakenda upplifði einhver ópægindi af að heyra orðanotkunina en rúmlega $85 \%$ hinsegin pátttakenda upplifði einhver ópægindi af að heyra orðanotkunina (Taylor o.fl., 2011).

Í Evrópu hafa einnig verið gerðar rannsóknir sem fjalla meðal annars um hómófóbísk uppnefni unglinga í skólum eins og fag, faggot, gay, lesbo (lessa, trukkur, trukkalessa), lezzie (lessa, trukkur, trukkalessa), dyke og queer í Hollandi (Collier, o.fl., 2013), pýskumælandi hluta Sviss (Weber og Gredig, 2018) og í Noregi (Slaatten o.fl., 2014; Slaatten og Gabrys, 2014). Í rannsókn Collier o.fl. (2013) var meðal annars skoðað hvaða nemendahópar væru líklegastir til að upplifa hómófóbísk uppnefni eins og fag, gay, lesbo og dyke (gagnkynhneigðir strákar, gagnkynhneigðar stelpur, samkynhneigðir/tvíkynhneigðir strákar og samkynhneigðar/tvíkynhneigðar stelpur). Niðurstöður rannsóknarinnar bentu til að samkynhneigðir/tvíkynhneigðir strákar væru 
líklegastir til að upplifa uppnefnin (83,3\%) og gagnkynhneigðir strákar næst líklegastir (62,6\%). Gagnkynhneigðar stelpur voru ólíklegastar til að upplifa hómófóbísk uppnefni (31,2\%) og samkynhneigðar/tvíkynhneigðar stelpur næst ólíklegastar (48,3\%).

Rannsókn Weber og Gredig (2018) fjallaði meðal annars um yrta hómófóbíu sem var skilgreind sem hómófóbísk uppnefni (gay, fag og queer notuð yfir einhvern sem pátttakendum líkaði ekki við), frasarnir that's so gay og no homo, að segja brandara um samkynhneigð, gera grín að einhverjum sem var samkynhneigður og gera grín að strák sem hagaði sér kvenlega. Niðurstöður rannsóknarinnar sýndu að meirihluti pátttakenda $(85,4 \%)$ hafði sýnt yrta hómófóbíu en strákar voru líklegri en stelpur til að sýna yrta hómófóbíu par sem 95,2\% stráka hafði sýnt hegðunina en $76 \%$ stúlkna. Algengasta form yrtrar hómófóbíu var notkun frasanna that's so gay og no homo $(65,1 \%)$, næst algengasta formið var að gera grín að strák sem sýndi kvenlega hegðun $(56,9 \%)$ og priðja algengasta formið var notkun hómófóbískra uppnefna yfir einstaklinga sem pátttakendum líkaði ekki við.

Rannsókn Slaatten o.fl. (2014) fjallaði meðal annars um algengi uppnefna sem tengjast samkynhneigð (eins og gay, fag og lesbo) og við/um hvern orðalagið var notað. Niðurstöðurnar bentu til að strákar væru líklegri en stelpur til að kalla bæði stráka (74\% á móti 54\%) og stelpur (34\% á móti 29\%) uppnefnum sem tengdust samkynhneigð. Strákar voru líklegri til að nota uppnefnin yfir einhvern sem var gagnkynhneigður frekar en yfir einhvern sem var samkynhneigður og vin frekar en einhvern sem peim líkaði ekki við, slíkan mun var ekki að finna hjá stelpum. Bæði strákar og stelpur voru líklegri til að nota uppnefnin yfir vini og einhvern sem peim líkaði ekki við en ókunnuga.

Rannsókn Slaatten og Gabrys (2014) fjallaði meðal annars um ástæður pess að hómófóbísk uppnefni eins og gay, faggot og lezzie voru notuð í norskum skólum. Niðurstöðurnar sýndu að strákar voru líklegri en stelpur til að nota uppnefnin. Strákar voru einnig líklegri en stelpur til að verða fyrir barðinu á uppnefnunum. Algengasta ástæða pess að strákar voru uppnefndir var að peir fylgdu ekki viðmiðum um karlmennsku (um 40\%), næst algengasta ástæðan var að pátttakendum líkaði ekki hegðun peirra (rúmlega 37\%) og priðja algengasta ástæðan var vinaleg stríðni (tæplega 34\%). Algengasta ástæða pess að stelpur voru uppnefndar var að pátttakendum líkaði ekki hegðun peirra (20\%), næst algengasta ástæðan var vinaleg stríðni (tæplega 19\%) og priðja algengasta ástæðan var að pær fylgdu ekki viðmiðum um kvenleika (tæplega 12\%).

Á Íslandi hefur verið athugað hvernig hið gagnkynhneigða regluveldi og heterósexismi birtast nemendum í íslenskum framhaldsskólum. Jón Ingvar Kjaran og Ingólfur Ásgeir Jóhannesson (2010) fjölluðu um reynslu samkynhneigðra stráka af heterósexisma í íslenskum framhaldsskólum en strákarnir sögðu frá pví hvernig gagnkynhneigð var ríkjandi í viðmiðum skólanna, umhverfi og orðræðu. Birtingarmyndirnar voru til dæmis frásagnir og umræður sem einkenndust af gagnkynhneigð, skilningsleysi par sem gagnkynhneigðum póttu persónulegar spurningar eðlilegar og skortur á fyrirmyndum pví fáir voru komnir út í framhaldsskóla (Jón Ingvar Kjaran og Ingólfur Ásgeir Jóhannesson, 2010).

Birtingarmyndir hins gagnkynhneigða regluveldis hafa einnig verið skoðaðar innan kennslustofunnar, leikfimisalarins og búningsklefans. Innan kennslustofunnar gátu pær falist í notkun úreltra eða niðrandi orða eins og kynvillingur í kennslubók eða kynskiptingur í umfjöllun kennara. Einnig gat kennari gefið sér gagnkynhneigð nemanda, til dæmis með pví að leiðrétta verkefni svo frásögnin varð gagnkynhneigð. Birtingarmyndirnar voru aðrar í leikfimisalnum par sem áhersla var á fótbolta meðal stráka og voru orðin hommi og faggi notuð sem uppnefni. Í búningsklefanum virtust gagnkynhneigðir nemendur aftur á móti telja að samkynhneigðir löðuðust sjálfkrafa að öllum af sama kyni (Jón Ingvar Kjaran og Ingólfur Ásgeir Jóhannesson, 2011).

Rannsókn Jóns Ingvars Kjarans (2016) lýsti pví hvernig orðanotkun íslenskra framhaldsskólanemenda einkenndist af heterósexisma og viðmiðum um útlit kynjanna. Niðurstöður 
rannsóknarinnar bentu meðal annars til að strákar voru líklegri til að nota orð á borð við faggalegur yfir karla/stráka og trukkur yfir konur/stelpur sem fylgdu ekki kynjuðum útlitsviðmiðum. Einnig voru peir líklegri til að nota faggalegt yfir mynd af tveimur strákum að kyssast (Jón Ingvar Kjaran, 2016).

\section{Aðferð og gögn}

\section{Pátttakendur og mælitæki}

Rannsóknin byggir á megindlegum hluta niðurstaðna rannsóknar sem gerð var fyrir meistaraverkefni fyrri höfundar en sú rannsókn var blönduð. Megindlegi hlutinn byggði á spurningakönnun sem pótti heppileg til að skoða algengi heterósexískrar orðanotkunar líkt og í rannsóknum Kosciw o.fl. (2016) og Taylor o.fl. (2011). Notkun spurningakönnunar pótti einnig gagnleg til að skoða mun á orðanotkun drengja og stúlkna líkt og í rannsóknum Burn (2000), Jóns Ingvars Kjarans (2016), Slaatten o.fl. (2014), Slaatten og Gabrys (2014) og Weber og Gredig (2018) og áhrif pess að heyra orðanotkunina á pátttakendur líkt og í rannsóknum Kosciw o.fl. (2016) og Taylor o.fl. (2011). Einnig voru skoðaðar pær aðstæður sem orðanotkunin átti sér stað í, sem sagt innan skóla, á netinu og annars staðar samanborið við utan skóla.

Notast var við frumsamda spurningakönnun með 11 spurningum. Spurningar um kyn og fæðingarár voru báðar opnar. Kosið var að hafa spurningu um fæðingarár opna pví talið var að spurningunni væri auðsvarað, hún væri skýr og engin hætta á misskilningi. Einnig var kosið að hafa spurningu um kyn opna til að bjóða pátttakendum að skilgreina kyn sitt með eigin orðum frekar en að búa til skilgreiningar eða flokka sem henta ekki öllum. Kyn pátttakenda var flokkað í prennt við úrvinnslu ganga en allir pátttakendur skilgreindu kyn sitt. Flokkarnir voru karlkyn (pátttakendur notuðu karl, karlkyn, kk, strákur og pess háttar), kvenkyn (pátttakendur notuðu kona, stelpa, kvenkyn, kvk og pess háttar) og regnhlífarhugtakið trans (pátttakendur notuðu kynjaskilgreiningar sem bentu til að peir voru ekki sískynja). Samkvæmt síðu Trans Ísland (e.d.-c) nær hugtakið trans yfir fjölda ólíkra kynjaskilgreininga par sem kyngervi, kynupplifun og kyntjáning samræmist ekki líffræðilegu kyni. Hugtakið pótti pví heppilegt til að lýsa peim einstaklingum sem notuðu ekki sískynja kynjaskilgreiningu. Einnig pótti ólíklegt að pátttakendur sem ekki notuðu sískynja kynjaskilgreiningar yrðu nógu margir til að skipta peim hópi frekar.

Spurningar um hererósexíska orðanotkun voru með svarmöguleika á Likert-kvarða og pótti hentugast að hafa sumar spurningarnar í liðum par sem hver liður skilgreindi eitt form heterósexískrar orðanotkunar (sjá hér að framan) og pátttakendur beðnir að merkja við viðeigandi svarmöguleika. Peir höfðu val um „oft á dag“, „,nokkrum sinnum á dag“, ,„kannski einu sinni á dag“, „,nokkrum sinnum í viku“, „,nokkrum sinnum undanfarinn mánuð“, ,einu sinni til tvisvar undanfarinn mánuð“ og ,aldrei““.

Pátttakendur voru einnig beðnir að meta hversu oft peir heyrðu aðra, líkt og bekkjarfélaga eða vini, nota heterósexískt orðalag undanfarinn mánuð og merkja við viðeigandi svarmöguleika sem voru peir sömu og í spurningunni um eigin orðanotkun. Pátttakendur voru einnig beðnir að meta hversu líklegt eða ólíklegt pað væri að peir notuðu heterósexískt orðalag 1 aðstæðunum „utan skóla“, „á skólalóðinni“, „,á göngum skólans“, „,í kennslustofum“, „1 ípróttasalnum“, „1́ búningsklefanum“, „á netinu“ og ,,annars staðar“. Deir voru beðnir að merkja í viðeigandi reit og svarmöguleikarnir sem peim buðust voru „líklegt“, frekar líklegt“, hvorki né“, „frekar ólíklegt" og ,ólíklegt“.

Að lokum voru pátttakendur beðnir að meta hversu mikil eða lítil ópægindi peir upplifðu af að heyra heterósexíska orðanotkun og peir beðnir að merkja við viðeigandi reit. Svarmöguleikarnir voru „,mikil ópægindi“, „,nokkuð mikil ópægindi“, ,einhver ópægindi“, „engin ópægindi“, „hlutlaus“ og „veit ekki““. Ákveðið var að bjóða upp á svarmöguleikann „hlutlaus“ til að bjóða 
upp á svarmöguleika fyrir pá sem mögulega vildu ekki taka afstöðu til peirra tilfinninga sem orðin gæetu hafa vakið og væru par af leiðandi hlutlausir.

Hluti af pví að heyra heterósexískt orðalag fólst í að pví væri beint að pátttakendum sjálfum. Hins vegar gerði spurningin ekki greinarmun á að heyra heterósexísku orðalagi beint að öðrum eða pátttakendum sjálfum og var pessi háttur hafður á til að halda spurningalistanum sem stystum. Fyrir vikið var ekki hægt að gera greinarmun á pessu tvennu pó hugsanlegt sé að pað veki frekar ópægindi meðal pátttakenda að heyra heterósexískt orðalag pegar pví er beint að peim.

Spurningalistinn var forprófaður í íslenskum framhaldsskóla á höfuðborgarsvæðinu til að gæta pess að hann væri skiljanlegur en pátttakendur forprófunarinnar voru 44 og höfðu allir náð 18 ára aldri. Spurningalistinn var lagfærður með hliðsjón af forprófuninni og athugasemdum pátttakenda hennar fyrir fyrirlögn.

Pátttakendur rannsóknarinnar voru 149 nemendur, 18 ára og eldri, í premur íslenskum framhaldsskólum. Pátttakendur voru fæddir á árunum 1993-1998 en meðalaldurinn var 19,9 ár. Fjöldi pátttakenda sem skilgreindi sig sem karlkyn var 67 (45\%), fjöldi pátttakenda sem skilgreindi sig sem kvenkyn var 81 (rúmlega 54\%) en 1 (tæplega 1\%) pátttakandi notaði ekki sískynja kynjaskilgreiningu og var pví flokkaður undir regnhlífarhugtakið trans.

Möguleiki var á að pátttakendur rannsóknarinnar notuðu félagslega æskilegan svörunarstíl (e. social desirability bias) við svörun spurningar um ýmis form heterósexísks orðalags enda orðalagið neikvætt. Svörunarstíllinn felst í að pátttakendur gefa svör sem peir telja að séu samfélagslega sampykkt (Elmes, Kantowitz og Roediger, 2006). Efni og form rannsóknarinnar gerir pað að verkum að ómögulegt er að koma alveg í veg fyrir slíkan svörunarstíl. Til að minnka líkur á honum var gætt að pví hvernig hugtökin heterósexismi og hið gagnkynhneigða regluveldi voru útskýrð fyrir pátttakendum. Líklegt pótti að ef fjallað væri um mismununina sem fælist í hugtökunum væru líkur á félagslega æskilegum svörunarstíl meiri. Dví voru hugtökin útskýrðá pá leið að heterósexismi fæli í sér tilhneiginguna til að gera ráð fyrir að allir væru gagnkynhneigðir (Jackson, 2006; Pharr, 1988) og að hið gagnkynhneigða regluveldi fælist í gagnkynhneigðri menningu og viðmiðum (Donelson og Rogers, 2004; Warner, 1993). Spurningalistinn byggði einnig á minni pátttakenda um eigin orðanotkun en óvíst er hvort pátttakendur hafi réttilega munað hversu oft eða sjaldan peir notuðu tiltekin orð/orðalag eins og lýst var (Elmes o.fl., 2006). Til að koma til móts við pátttakendur og par með tryggja betur réttmæti niðurstaðna var spurt um orðanotkun undanfarinn mánuð frekar en lengra aftur í tímann.

\section{Gagnaöflun og greining}

Gagnaöflun fór fram árið 2017 í premur framhaldsskólum á höfuðborgarsvæðinu, sendur var tölvupóstur á 11 skóla og athugað hvort peir væru reiðubúnir að taka pátt. Tölvupósturinn greindi frá umfjöllunarefni rannsóknarinnar ásamt aldursskilyrðum (18 ára). Skólarnir sem buðust til pátttöku voru ýmist með bekkjar- eða áfangakerfi en spurningalistinn var lagður fyrir í ólíkum fögum. Fjöldi pátttakenda frá hverjum skóla var misjafn, pátttakendur frá Skóla 1 voru 30 (20\%), pátttakendur frá Skóla 2 voru 86 (58\%) og pátttakendur frá Skóla 3 voru 33 (22\%).

Engin skilyrði voru sett um pekkingu eða fræðslu sem pátttakendur gætu hafa fengið um efnið til að útiloka ekki mögulega pátttakendur pó slíkt gæti haft áhrif á svör peirra. Dátttakendur voru jafnframt ekki spurðir út í slíka fræðslu eða pekkingu pví reynt var að safna sem minnstum persónugreinanlegum upplýsingum og halda listanum eins stuttum og hnitmiðuðum og kostur var til að auka líkur á pátttöku og að öllum spurningum væri svarað. Listinn var lagður fyrir í upphafi kennslustunda en fyrirlögnin var aðlöguð að pörfum kennaranna sem sampykktu fyrirlögnina. Fyrirlögnin fór pannig fram að kennararnir kynntu rannsakanda fyrir nemendum sem sagði peim frá rannsókninni og/eða nemendur lásu upplýst sampykki par sem efni rannsóknarinnar var útskýrt áđur en peir ákváđu pátttöku. Nemendurnir fengu upplýst sampykki og spurningalistann 
í hvítu ómerktu umslagi sem peir innsigluðu áður en peir skiluðu inn til að tryggja nafnleynd. Deir nemendur sem sampykktu pátttöku svöruðu pví næst listanum. Eftir að spurningalistanum hafði verið svarað og skilað inn höfðu nemendur tækifæri til að spyrja spurninga og/eða senda tölvupóst á netfang rannsakanda.

Tölfræðileg úrvinnsla gagnanna fór fram í Excel, $R$ og JMP 13. Notað var kí-kvaðrat próf (e. chisquare test) til að athuga hvort munur væri á hópunum og forritin JMP 13 og $R$ póttu heppilegri til að reikna pað. Gögnin voru á Likert-kvarða en mikil skekkja var í peim pví meirihluti pátttakanda taldi sig ekki hafa notað orðalagið og purfti pví að sameina pá sem höfðu notað orðalagið til að ná lágmarks væntigildi um fimm í 20\% reita töflunnar (Daniel, 2010). Dví var gögnunum breytt í nafnkvarða par sem pátttakendur skiptust á milli peirra sem höfðu notað heterósexískt orðalag og peirra sem höfðu ekki notað pað undanfarinn mánuð. Skekkjan í einum lið spurningarinnar um algengi orðanotkunar (transa/tranný) var pað mikil að væntigildið náði ekki fimm í 20\% reita töflunnar og pví var nákvæmt próf Fishers (e. Fishers exact test) notað (Daniel, 2010). Einnig var mikil skekkja pegar spurt var um hversu líklega eða ólíklega pátttakendur töldu sig til að nota orðalagið í mismunandi aðstæðum par sem margir pátttakendur töldu pað ólíklegt. Kí-kvaðrat próf er ekki viðkvæmt fyrir skekkju í gögnum og hægt að nota pað á Likert-kvarða pó skekkja sé mikil (McHugh, 2013). Til að reikna lýsandi tölfræði var notast við Excel.

\section{Siðferðileg álitamál}

Siðferðileg álitamál rannsóknarinnar voru prjú, að pátttakendur væru ekki orðnir 18 ára, að pátttakendum hafi pótt ópægilegt að svara einhverjum spurningum og að efni rannsóknarinnar var ekki fyllilega skýrt fyrir pátttakendum. Til að tryggja að pátttakendur væru orðnir 18 ára var aldursskilyrðið tekið fram í tölvupóstinum sem sendur var á skólana pegar óskað var eftir pátttöku. Einnig var pað tekið fram í bæði upplýstu sampykki og í kynningu á rannsókninni. Að lokum voru pátttakendur beðnir að tilgreina fæðingarár sitt svo ekki væru notuð gögn frá einhverjum sem ekki hefði nád tilskyldum aldri.

Pátttakendum gæti hafa pótt ópægilegt að svara einhverjum spurningum pó pað hafi ekki verið raunin í forprófuninni. Í upplýstu sampykki var pví tekið fram að pátttakendum væri frjálst að sleppa pví að svara spurningum og peim sérstaklega bent á að sleppa spurningum sem peim póttu ópægilegar í kynningunni.

Баð er réttur pátttakenda að vita hvert rannsóknarefnið er áður en peir sampykkja pátttöku (Sigurður Kristinsson, 2013) en hægt er að álykta аð pað gangi ekki eftir pegar hugtök rannsóknarinnar eru ekki fyllilega útskýrð. Dví voru pátttakendum gefin dæmi um spurningar sem peir áttu von á og peir hvattir til að skoða spurningalistann ádur en pátttaka var sampykkt, bæði í kynningunni og upplýstu sampykki. Dví ættu pátttakendur að hafa haft skýra hugmynd um efni rannsóknarinnar ádur en peir ákváđu pátttöku.

\section{Niðurstöður}

Niðurstöðukaflinn fjallar um heterósexíska orðanotkun eftir kyngervi pátttakenda par sem algengi hvers forms orðanotkunarinnar kemur fram, hversu líklega pátttakendur töldu sig til að nota heterósexískt orðalag í ólíkum aðstæðum innan skóla, á netinu og annars staðar samanborið við utan skóla og hvaða áhrif pátttakendur upplifðu af að heyra mismunandi afbrigði orðalagsins. Í sumum tilfellum svöruðu pátttakendur ekki öllum liðum eða spurningum en notuð voru pau svör sem pátttakendur gáfu.

Til að athuga hvort munur væri milli skólanna með tilliti til algengi mismunandi heterósexískrar orðanotkunar voru gerð kí-kvaðrat próf milli skólanna eða Fisher-próf ef væntigildi náði ekki fimm í 20\% reita töflunnar (Daniel, 2010). Munurinn var eingöngu marktækur í tveimur 
tilfellum, milli Skóla 2 og Skóla 3 varðandi notkun á orðinu trukkalessa um stelpu sem hegðaði sér ekki kvenlega $\left(\mathrm{X}^{2}(1, \mathrm{n}=118)=4.7032, p=0.03\right)$. Einnig var munur á milli Skóla 1 og Skóla 2 á notkun orðsins kynskiptingur yfir trans fólk $\left(\mathrm{X}^{2}(1, \mathrm{n}=116)=4.3958, p=0,036\right)$.

\section{Orðanotkun eftir kyngervi}

Dessi hluti skoðar kynjamun og algengi heterósexískrar orðanotkunar. Einn pátttakandi flokkaðist undir regnhlífarhugtakið trans og voru svör hans ekki notuð til skoða kynjamun og algengi pví hægt er að rekja pau. Heildardreifing svaranna, svörun eftir kyni og p-gildi marktektarprófs eru í töflu 1.

Tafla 1. Orðanotkun eftir kyngervi

\begin{tabular}{lccccccc}
\hline & \multicolumn{2}{c}{ Kk } & \multicolumn{2}{c}{ Kvk } & \multicolumn{2}{c}{ Alls } & p-gildi \\
\hline & $\begin{array}{c}\text { Notuðu } \\
\text { ekki }(\%)\end{array}$ & $\begin{array}{c}\text { Notuðu } \\
(\%)\end{array}$ & $\begin{array}{c}\text { Notuðu } \\
\text { ekki }(\%)\end{array}$ & $\begin{array}{c}\text { Notuðu } \\
(\%)\end{array}$ & $\begin{array}{c}\text { Notuðu } \\
\text { ekki }(\%)\end{array}$ & $\begin{array}{c}\text { Notuðu } \\
(\%)\end{array}$ & \\
\hline Gay fyrirbæri & $45(67 \%)$ & $22(33 \%)$ & $74(91 \%)$ & $7(9 \%)$ & $119(80 \%)$ & $29(20 \%)$ & $0,0002 \star$ \\
Gay hegðun & $48(72 \%)$ & $19(28 \%)$ & $78(96 \%)$ & $3(4 \%)$ & $126(85 \%)$ & $22(15 \%)$ & $<0,0001 \star$ \\
No homo & $47(70 \%)$ & $20(30 \%)$ & $77(95 \%)$ & $4(5 \%)$ & $124(84 \%)$ & $24(16 \%)$ & $<0,0001 \star$ \\
Faggi yfir strák & $39(58 \%)$ & $28(42 \%)$ & $77(95 \%)$ & $4(5 \%)$ & $116(78 \%)$ & $32(22 \%)$ & $<0,0001 \star$ \\
Faggi/faggalegt & $18(27 \%)$ & $49(73 \%)$ & $49(61 \%)$ & $31(39 \%)$ & $67(46 \%)$ & $80(54 \%)$ & $<0,0001 \star$ \\
Lessa & $56(84 \%)$ & $11(16 \%)$ & $75(93 \%)$ & $6(7 \%)$ & $131(89 \%)$ & $17(11 \%)$ & 0,087 \\
Trukkalessa & $50(75 \%)$ & $17(25 \%)$ & $68(84 \%)$ & $13(16 \%)$ & $118(80 \%)$ & $30(20 \%)$ & 0,16 \\
Kynskiptingur & $47(70 \%)$ & $20(30 \%)$ & $50(62,5 \%)$ & $30(37,5 \%)$ & $97(66 \%)$ & $50(34 \%)$ & 0,33 \\
Transa/tranný & $61(91 \%)$ & $6(9 \%)$ & $79(99 \%)$ & $1(1 \%)$ & $140(95 \%)$ & $7(5 \%)$ & $0,0473 \star$ \\
\hline
\end{tabular}

Marktekt miðast við p lægra en eða jafnt og 0,05

Strákar voru marktækt líklegri en stelpur til að nota orðin gay til að lýsa pví að fyrirbæri $\left(\mathrm{X}^{2}(1, \mathrm{n}\right.$ $=148)=13,623, \mathrm{p}=0,0002)$ eða hegðun $\left(\mathrm{X}^{2}(1, \mathrm{n}=148)=17,612, p<0,0001\right)$ væri heimskuleg eða asnaleg og frasann no homo til að ítreka gagnkynhneigð $\left(\mathrm{X}^{2}(1, \mathrm{n}=148)=16,75, p<0,0001\right)$. Deir voru einnig líklegri til að hafa notað faggi yfir strák sem hegðaði sér ekki karlmannlega $\left(\mathrm{X}^{2}\right.$ $(1, \mathrm{n}=148)=29,387, p<0,0001)$ eða faggalegt/faggi um hegðun sem peim líkaði ekki $\left(\mathrm{X}^{2}(1, \mathrm{n}\right.$ $=147)=17,38, p<0,0001)$. Jafnframt voru strákar líklegri til að hafa notað orðin transa/tranný um trans einstakling $(\mathrm{p}=0,0473)$. Nákvæmt próf Fishers var notað pví væntigildi reita töflunnar náði ekki 5 í yfir 20\% tilfella (Daniel, 2010, sjá töflu 1).

Munur var ekki marktækur á notkun orðanna lessa $\left(\mathrm{X}^{2}(1, \mathrm{n}=148)=2,928, p=0,087\right)$ og trukkalessa $\left(\mathrm{X}^{2}(1, \mathrm{n}=148)=1,972, p=0,16\right)$ yfir stelpu sem hegðaði sér ekki kvenlega pó hærra hlutfall drengja hafi notað orðalagið. Munur á notkun orðsins kynskiptingur um trans fólk var heldur ekki marktækur $\left(\mathrm{X}^{2}(1, \mathrm{n}=147)=0,951, p=0,33\right)$ en hærra hlutfall stelpna hafði notað orðið (sjá töflu 1).

Flestir pátttakendur höfðu notað orðin faggi/faggalegt pví peim líkaði ekki hegðun (sjá töflu 1). Hlutfall pátttakenda sem hafði notað orðalagið einu sinni til tvisvar undanfarinn mánuð var $26 \%$ en $29 \%$ höfðu notað pað oftar. Næst algengasta orðalagið var notkun orðsins kynskiptingur (sjá töflu 1). Hlutfall peirra sem höfðu notað orðið einu sinni til tvisvar undanfarinn mánuð var $21 \%$ en 13\% höfðu notað orðið oftar. Priðja algengasta orðanotkunin var notkun orðsins faggi yfir strák sem hegðaði sér ekki karlmannlega (sjá töflu 1).

Dátttakendur voru einnig beðnir að meta algengi pess að heyra aðra nota heterósexískt orðalag til að skoða algengi orðalagsins í umhverfi pátttakenda. Hlutfall peirra sem hafði heyrt heterósexískt 
orðalag undanfarinn mánuð var $94 \%$ sem pýðir að 6\% heyrðu ekki heterósexíska orðanotkun undanfarinn mánuð.

\section{Heterósexísk orðanotkun í ólíkum aðstæðum}

Athugað var hvort pátttakendur teldu sig jafn líklega til að nota heterósexískt orðalag í ólíkum aðstæðum innan skóla, á netinu og annars staðar samanborið við utan skóla. Tafla 2 sýnir dreifingu svara pátttakenda eftir aðstæðum, fjölda sem svaraði hverjum lið og p-gildi allra aðstæðna samanborið við utan skóla. Marktektarprófið (kí-kvaðrat próf) gefur pó eingöngu upp milli hvaða aðstæðna munur var marktækur en ekki milli hvaða reita (McHugh, 2013). Samanburður var gerður milli aðstæðnanna utan skóla og á skólalóðinni, á göngum skólans, í skólastofum, í ípróttatíma, í búningsklefanum, á netinu og annars staðar. Meira en helmingur pátttakenda taldi sig frekar ólíklega eða ólíklega til að hafa notað heterósexískt orðalag í peim aðstæðum sem spurt var um (sjá töflu 2).

Marktækur munur var milli aðstæðnanna utan skóla og priggja annarra aðstæðna, í skólastofunni $\left(\mathrm{X}^{2}(4, \mathrm{n}=296)=12,012, p=0,0173\right)$, í ípróttatíma $\left(\mathrm{X}^{2}(4, \mathrm{n}=295)=20,361, p=0,0004\right)$ og í búningsklefanum $\left(\mathrm{X}^{2}(4, \mathrm{n}=296)=18,299, p=0,0011\right)$. Munur milli aðstæðnanna utan skóla og annarra aðstæðna (á skólalóðinni $\left(\mathrm{X}^{2}(4, \mathrm{n}=296)=7,148, p=0,13\right)$, á göngum skólans $\left(\mathrm{X}^{2}\right.$ $(4, \mathrm{n}=296)=6,162, \mathrm{p}=0,19)$, á netinu $\left(\mathrm{X}^{2}(4, \mathrm{n}=296)=4,583, p=0,33\right)$ og annars staðar $\left(\mathrm{X}^{2}\right.$ $(4, \mathrm{n}=295)=4,573, p=0,33)$ var ekki marktækur (sjá töflu 2).

Tafla 2. Notkun heterósexísks orðalags í ólíkum aðstæðum

\begin{tabular}{lccccccc}
\hline & $\begin{array}{c}\text { Ólíklegt } \\
\mathbf{( \% )}\end{array}$ & $\begin{array}{c}\text { Frekar } \\
\text { ólklegt (\%) }\end{array}$ & $\begin{array}{c}\text { Hvorki } \\
\text { né (\%) }\end{array}$ & $\begin{array}{c}\text { Frekar } \\
\text { líklegt (\%) }\end{array}$ & $\begin{array}{c}\text { Líklegt } \\
\mathbf{( \% )}\end{array}$ & Alls (\%) & $\begin{array}{c}\text { p - } \\
\text { gildi }\end{array}$ \\
\hline Utan skóla & $67(45 \%)$ & $30(20 \%)$ & $21(14 \%)$ & $23(16 \%)$ & $7(5 \%)$ & $148(100 \%)$ & - \\
Á skólalóðinni & $88(59 \%)$ & $26(18 \%)$ & $17(11 \%)$ & $13(9 \%)$ & $4(3 \%)$ & $148(100 \%)$ & 0,13 \\
Gangar skólans & $86(58 \%)$ & $24(16 \%)$ & $20(14 \%)$ & $13(9 \%)$ & $5(3 \%)$ & $148(100 \%)$ & 0,19 \\
Í skólastofum & $93(63 \%)$ & $28(19 \%)$ & $13(9 \%)$ & $11(7 \%)$ & $3(2 \%)$ & $148(100 \%)$ & $0,0173 \star$ \\
Í ípróttatíma & $103(70 \%)$ & $20(14 \%)$ & $13(9 \%)$ & $8(5 \%)$ & $3(2 \%)$ & $147(100 \%)$ & $0,0004^{\star}$ \\
Búningsklefinn & $103(70 \%)$ & $15(10 \%)$ & $14(9 \%)$ & $12(8 \%)$ & $4(3 \%)$ & $148(100 \%)$ & $0,001{ }^{\star}$ \\
Á netinu & $84(57 \%)$ & $23(15 \%)$ & $17(12 \%)$ & $16(11 \%)$ & $8(5 \%)$ & $148(100 \%)$ & 0,33 \\
Annars staðar & $72(49 \%)$ & $26(18 \%)$ & $30(20 \%)$ & $14(10 \%)$ & $5(3 \%)$ & $147(100 \%)$ & 0,33 \\
\hline
\end{tabular}

^Marktekt miðast við $p$ lægra en eða jafnt og 0,05

\section{Áhrif heterósexískrar orðanotkunar á nemendur í framhaldsskólum}

Kannað var hvort pátttakendur upplifðu ópægindi af að heyra heterósexíska orðanotkun pegar orðin beindust að peim. Tafla 3 sýnir dreifingu svara fyrir hvert form heterósexísks orðalags og hversu margir pátttakendur svöruðu hverjum lið.

Hæst hlutfall pátttakenda fann fyrir ópægindum af notkun orðsins trukkalessa um stelpu sem hegðaði sér ekki kvenlega (65\%). Notkun orðsins gay yfir heimskulega eða asnalega hegðun kom næst verst við pátttakendur en 64\% upplifðu ópægindi af orðanotkuninni. Orðanotkunin sem olli priðja hæsta hlutfall pátttakenda ópægindum að heyra var notkun orðsins faggi (63\%) yfir strák sem hegðaði sér ekki karlmannlega (sjá töflu 3).

Sjaldgæfast var að pátttakendur upplifðu ópægindi af notkun orðsins kynskiptingur um trans fólk (32\%). Næst lægst hlutfall pátttakenda upplifði ópægindi af að heyra orðin transa/tranný (45\%) um trans fólk. Notkun orðanna faggi/faggalegt pví viðkomandi líkaði ekki hegðun annars aðila olli priðja lægsta hlutfalli pátttakenda ópægindum (48\%, sjá töflu 3).

Hæst hlutfall pátttakenda var hlutlaus eða óviss varðandi upplifun sína af notkun orðanna kynskiptingur (34\%) og trannsa/tranný (36\%). Hlutfall pátttakenda sem var hlutlaus eða óviss 
varðandi aðra orðanotkun var á bilinu 18-21\%. Hæst hlutfall pátttakenda upplifði auk pess engin ópægindi af að heyra orðið kynskiptingur (rúmlega 34\%). Næst algengast var að orðin faggi/faggalegt ollu pátttakendum sem heyrðu pað engum ópægindum (32\%) og frasinn no homo fylgdi svo en 29\% upplifðu ekki ópægindi af að heyra hann (sjá töflu 3).

Tafla 3. Áhrif heterósexískrar orðanotkunar á nemendur í framhaldsskólum

\begin{tabular}{lccccccc}
\hline & $\begin{array}{c}\text { Veit } \\
\text { ekki } \\
(\%)\end{array}$ & $\begin{array}{c}\text { Hlut- } \\
\text { laus } \\
(\mathbf{\%})\end{array}$ & $\begin{array}{c}\text { Engin } \\
\text { ópægindi } \\
(\%)\end{array}$ & $\begin{array}{c}\text { Einhver } \\
\text { ópgindi } \\
(\mathbf{\%})\end{array}$ & $\begin{array}{c}\text { Nokkuð mikil } \\
\text { ópægindi } \\
(\%)\end{array}$ & $\begin{array}{c}\text { Mikil } \\
\text { ópægindi } \\
(\%)\end{array}$ & $\begin{array}{c}\text { Alls } \\
\mathbf{( \% )}\end{array}$ \\
\hline Gay fyrirbæri & $6(4 \%)$ & $25(17 \%)$ & $29(20 \%)$ & $28(19 \%)$ & $38(26 \%)$ & $21(14 \%)$ & $147(100 \%)$ \\
Gay hegðun & $8(6 \%)$ & $18(12 \%)$ & $27(18 \%)$ & $27(18 \%)$ & $42(29 \%)$ & $25(17 \%)$ & $147(100 \%)$ \\
No homo & $7(5 \%)$ & $23(15 \%)$ & $42(29 \%)$ & $40(27 \%)$ & $19(13 \%)$ & $16(11 \%)$ & $147(100 \%)$ \\
Faggi yfir strák & $7(5 \%)$ & $20(13 \%)$ & $28(19 \%)$ & $29(20 \%)$ & $18(12 \%)$ & $45(31 \%)$ & $147(100 \%)$ \\
Faggi/faggalegt & $10(7 \%)$ & $19(13 \%)$ & $47(32 \%)$ & $25(17 \%)$ & $20(13 \%)$ & $26(18 \%)$ & $147(100 \%)$ \\
Lessa & $9(6 \%)$ & $18(12 \%)$ & $30(21 \%)$ & $24(16 \%)$ & $39(27 \%)$ & $26(18 \%)$ & $146(100 \%)$ \\
Trukkalessa & $11(8 \%)$ & $15(10 \%)$ & $25(17 \%)$ & $31(21 \%)$ & $30(20 \%)$ & $35(24 \%)$ & $147(100 \%)$ \\
Kynskiptingur & $17(12 \%)$ & $33(22 \%)$ & $50(34 \%)$ & $17(12 \%)$ & $10(7 \%)$ & $19(13 \%)$ & $146(100 \%)$ \\
Transa/tranný & $22(15 \%)$ & $31(21 \%)$ & $28(19 \%)$ & $22(15 \%)$ & $13(9 \%)$ & $30(21 \%)$ & $146(100 \%)$ \\
\hline
\end{tabular}

\section{Umræður}

Strákar voru líklegri til að nota flest form heterósexísks orðalags en stelpur pó að ekki hafi verið marktækur munur í öllum tilvikum. Munur var á algengi orðanna en flestir pátttakendur (54\%) höfðu notað orðin faggi/faggalegt um hegðun sem viðkomandi líkaði ekki. Næst algengust var notkun orðsins kynskiptingur yfir trans fólk (34\%). Sjaldgæfust var notkun orðanna transa/tranný um trans fólk (5\%). Hlutfall pátttakenda sem hafði notað önnur form heterósexísks orðalags var 11-22\%. Hins vegar höfðu $94 \%$ heyrt aðra nota heterósexískt orðalag undanfarinn mánuð. Pátttakendur voru ólíklegir til að nota heterósexískt orðalag í peim aðstæðum sem spurt var um og peir voru ólíklegri til að nota pað í kennslustofum, í búningsklefanum og í ípróttatíma en utan skóla. Heterósexískt orðalag hafði einnig misjöfn áhrif á pátttakendur en öll form pess ollu 4565\% pátttakenda ópægindum fyrir utan orðið kynskiptingur en lægst hlutfall pátttakenda fann til ópæginda af pví (32\%). Næst lægst hlutfall pátttakenda fann til ópæginda af notkun orðanna transa/tranný (45\%).

Munur var á algengi orðsins trukkalessa milli Skóla 2 og Skóla 3 og á orðinu kynskiptingur milli Skóla 1 og Skóla 2 sem getur verið merki um ólíkan skólabrag innan peirra. Pátttakendur voru pó hlutfallslega fáir og pví getur samanburðurinn milli skólanna eingöngu gefið vísbendingar um mögulegan mun. Stærri rannsókn pyrfti til að gefa skýrari vísbendingar um mun á heterósexískri orðanoktun milli framhaldsskóla á Íslandi.

Strákar voru líklegri til að hafa notað gay yfir hegðun eða fyrirbæri sem pótti heimskulegt eða asnalegt og faggi og/eða faggalegt um að hegðun stráks væri ekki karlmannleg eða ef peim líkaði hún ekki. Peir voru einnig líklegri til að hafa notað frasann no homo og transa/tranný. Nokkuð samræmi er með pessum niðurstöðum og niðurstöðum rannsókna Nayak og Kehily (1996) og Pascoe (2005), sem pó eru eigindlegar og skoða tengsl karlmennsku við hómófóbíu, en einnig niðurstöðum megindlegra rannsókna Burn (2000), Slaatten o.fl. (2014), Slaatten og Gabrys (2014), Weber og Gredig (2018) og Jóns Ingvars Kjarans (2016). Niðurstöður rannsóknar Nayak og Kehily (1996) bentu til að ein birtingarmynd hómófóbíu væri notkun orðsins gay 
yfir stráka sem sýndu ekki æskilega hegðun. Í niðurstöðum rannsóknar Pascoe (2005) kom í ljós að strákar beindu skammaryrðinu fag hver að öðrum ef hegðun pótti ekki karlmannleg. Niðurstöður rannsóknar Burn (2000) benda til að strákar séu líklegri en stelpur til að nota fag og álíka orðalag en stelpur. Niðurstöður rannsóknar Slaatten o.fl. (2014) benda einnig til að strákar séu líklegri en stelpur til að nota uppnefni sem tengjast samkynhneigð. Niðurstöður rannsóknar Slaatten og Gabrys (2014) gefa vísbendingar um að strákar séu líklegri til að nota hómófóbísk uppnefni en stelpur. Niðurstöður rannsóknar Weber og Gredig (2018) gefa vísbendingar um að strákar séu líklegri en stelpur til að sýna yrta hómófóbíu. Í rannsókn Jóns Ingvars Kjarans (2016) benda niðurstöðurnar til að strákar séu líklegri en stelpur til að nota orð eins og faggalegt yfir mynd af strák sem uppfyllir ekki karlmannleg útlitsviðmið eða yfir tvo stráka að kyssast. Niðurstöður pessarar rannsóknar benda til að heterósexískt orðalag virðist tengjast karlmennsku frekar en kvenleika og styðja pví niðurstöður rannsókna Nayak og Kehily (1996), Pascoe (2005), Slaatten o.fl. (2014), Slaatten og Gabrys (2014), Weber og Gredig (2018) og Jóns Ingvars Kjarans (2016) sem benda til að heterósexismi eða hómófóbía tengist karlmennsku.

Heterósexísk orðanotkun var misjafnlega algeng eftir pví hvert form hennar var. Dátttakendur voru líklegastir til að hafa notað faggi/faggalegt um hegðun sem peim líkaði ekki. Hugtakið kærustufaggi var gefið sem dæmi í skilgreiningu rannsóknarinnar um hvernig faggi gæti verið hluti af orði (sjá hér að framan). Næst algengast var kynskiptingur um trans fólk. Sjaldgæfasta orðanotkunin var hins vegar transa/tranný um trans fólk sem gæti bent til að slík orðanotkun hafi ekki fest í sessi hérlendis.

Athugað hefur verið hversu algengt væri að hinsegin nemendur í bandarískum skólum heyrðu skammaryrði á borð við fag og $d y k e$, frasann no homo, neikvæða notkun orðsins gay eða uppnefnin tranny og he/she yfir trans einstaklinga (Kosciw o.fl., 2016). Einnig var gerð rannsókn í Kanada meðal gagnkynhneigðra og hinsegin nemenda og peir spurðir um algengi neikvæðrar notkunar orðsins gay og uppnefna á borð við faggot, lezbo, dyke og queer (Taylor o.fl., 2011). Dó að sú rannsókn sem hér er kynnt líkist bæði rannsóknum Kosciw o.fl. (2016) og Taylor o.fl. (2011) að pví leyti að báðar gefa pær hugmynd um algengi orðalags sem mætti skilgreina sem heterósexískt er samanburður erfiður pví í pessari rannsókn voru pátttakendur beðnir að meta algengi eigin orðanotkunar. Einnig er um ólík tungumál að ræða og ekki sjálfgefið að orðin hafi sömu merkingu. Í pessari rannsókn fjallaði ein spurning um algengi heterósexískrar orðanotkunar í áheyrn pátttakenda pó ekki hafi verið gerður greinarmunur á formum hennar. Í rannsóknum Kosciw o.fl. (2016) og Taylor o.fl. (2011) voru pátttakendur hins vegar spurðir hversu oft peir hefðu heyrt tiltekna orðanotkun.

Meirihluti pátttakenda taldi sig ólíklega/frekar ólíklega til að nota heterósexískt orðalag í peim aðstæðum sem spurt var um. Munur var milli aðstæðnanna í kennslustofum, í búningsklefanum og í ípróttatíma samanborið við utan skóla. Fleiri pátttakendur töldu sig líklegri til að nota orðalagið utan skóla en í hinum premur aðstæðunum. Stór hluti pátttakenda (84\%) taldi sig ólíklegan/ frekar ólíklegan til að nota orðalagið í ípróttatíma. Niðurstöđur rannsóknar Jóns Ingvars Kjarans og Ingólfs Ásgeirs Jóhannessonar (2011) bentu hins vegar til að strákar notuðu orðin hommi og faggi til að gera lítið úr hver öðrum í ípróttatíma. Dó hér sé ósamræmi á milli niðurstaðna rannsóknanna fór gagnaöflun rannsóknar Jóns Ingvars Kjarans og Ingólfs Ásgeirs Jóhannessonar (2011) fram með viðtölum sem gerir samanburð erfiðan, enda önnur rannsóknaraðferð. Par með er ekki sagt að heterósexískt orðalag sé aldrei notað í ípróttatíma pó flestir pátttakendur pessarar rannsóknar hafi talið sig frekar ólíklega/ólíklega til að nota orðalagið. Jafnvel er mögulegt að slík orðanotkun sé oft ómeðvituð, einkum pá i „hita leiksins“. Pátttakendur gætu pví verið ólíklegri til að muna eftir heterósexískri orðanotkun pegar peir svöruðu spurningalistanum en brigðult minni pátttakenda er einmitt einn af ókostum spurningalista sem treysta á að pátttakendur svari spurningum eftir minni (Elmes o.fl., 2006) líkt og í pessari rannsókn.

Pátttakendur rannsóknarinnar voru úr premur framhaldsskólum á höfuðborgarsvæðinu sem ýmist höfðu bekkjar- eða áfangakerfi. Allir pátttakendur höfðu auk pess náð 18 ára aldri og meðalaldurinn var 19,9 ára. Dátttakendur rannsóknarinnar voru 149 og pví gefa niðurstöðurnar 
einungis vísbendingar um heterósexíska orðanotkun í pessum premur framhaldsskólum en ekki heildstæða mynd á landsvísu. Niðurstöðurnar gefa heldur ekki vísbendingar um heterósexíska orðanotkun í öðrum bæjarfélögum, á landsbyggðinni eða á öðrum skólastigum en frekari rannsókna er pörf til að skera úr um algengi orðanotkunarinnar við pessar aðstæður.

Í pessari rannsókn var munur á pví hversu hátt hlutfall pátttakenda taldi sig hafa notað heterósexískt orðalag (5-54\% eftir formum orðalagsins) og hversu hátt hlutfall hafði heyrt aðra nota pað (94\%). Dessi munur getur hugsanlega skýrst af félagslega æskilegri svörun pátttakenda en frekari rannsókna er pörf til að ákvarða pað. Einnig er möguleiki að form rannsóknarinnar hafi haft áhrif par sem pátttakendur voru beðnir að rifja upp eigin orðanotkun en óvíst er hvort peir hafi metið hana réttilega. Frekari rannsóknir gætu til dæmis athugað algengi pess að pátttakendur heyri mismunandi form heterósexísks orðalags í íslenskum framhaldsskólum. Einnig gætu aðrar aðferðir en spurningalistar gagnast til að skoða orðalagið frekar, til dæmis viðtöl við gagnkynhneigða og sís eða hinsegin nemendur til að skoða peirra upplifun af orðanotkuninni.

Skoðað var hversu líklega pátttakendur töldu sig til að nota heterósexískt orðalag í ólíkum rýmum innan skólans. Munur á orðanotkun stráka og stelpna var ekki kannaður í mismunandi rýmum eða aðstæðum. Slíkt hefði pó getað gefið skýrari mynd af notkun heterósexísks orðalags innan framhaldsskólans. Einnig hefði verið áhugavert að skoða í hvaða rýmum nemendur framhaldsskóla heyrðu aðra nota orðalagið en pað var ekki gert í rannsókninni.

Könnuð voru áhrif ýmissa forma heterósexísks orðalags á pátttakendur pó munur á áhrifum á stráka og stelpur hafi ekki verið skoðaður. Einnig gæti verið áhugavert að skoða hvort hinsegin nemendur upplifi önnur áhrif af orðalaginu en gagnkynhneigðir og sís nemendur. Sú virðist vera raunin samkvæmt niðurstöðum rannsóknar Taylor o.fl. (2011) pví hærra hlutfall hinsegin pátttakenda upplifði ópægindi af neikvæðri notkun orðsins gay og skammaryrðunum faggot, lezbo, dyke og queer. Niðurstöður rannsókna Kosciw o.fl. (2012) og Kosciw o.fl. (2016) bentu til að meirihluti hinsegin nemenda upplifði einnig ópægindi af neikvæðri notkun orðsins gay og frasanum no homo.

Athygli vakti að orðið kynskiptingur var næst algengasta heterósexíska orðanotkunin en 34\% höfðu notað orðið undanfarinn mánuð. Dví vakna upp spurningar um ástæðu pess að orðið sé enn notað. Pörf er á frekari rannsóknum til að skýra hvers vegna algengi pessa orðs var meira heldur en flestra annarra heterósexískra orða.

Dátttakendur voru ólíklegri til að upplifa ópægindi af heterósexísku orðalagi um trans fólk. Einungis 32\% upplifðu ópægindi af orðinu kynskiptingur og 45\% af orðunum transa/tranný en ástæðurnar gætu verið áhugaverðar. Mögulega gætu trans málefni verið fjarlæg pátttakendum og erfitt fyrir pá að átta sig á peim. Einnig er möguleiki að pátttakendur hafi ekki gert sér grein fyrir að orðið kynskiptingur sé ekki viðeigandi yfir trans einstaklinga (Trans Ísland, e.d.-a). Dörf er á frekari rannsóknum til að skera úr um áhrif pekkingar á að heyra neikvæett orðalag um trans fólk eða nota slíkt orðalag. Einnig væri áhugavert að skoða ástæður pess að pátttakendur upplifa meiri ópægindi af að heyra annað heterósexískt orðalag eins og trukkalessa og faggi yfir stelpu eða strák sem hegðar sér ekki kvenlega eða karlmannlega og gay yfir asnalega/heimskulega hegðun. Mögulegt er pó að slíkt orðalag sé pátttakendum einfaldlega kunnugra en orðalag sem tengist trans fólki sérstaklega með tilliti til pess að Trans Ísland sem berst fyrir réttindum trans fólks var ekki stofnað fyrr en 2007 (Trans Ísland, e.d.-b). Réttindabarátta samkynhneigðra hefur hins vegar varað lengur hérlendis en Samtökin '78 voru stofnuð 1978 ('óra Björk Hjartardóttir, 2005).

Heterósexísk orðanotkun getur verið ómeðvituð eða falist í notkun óviðeigandi orða, líkt og virðist eiga við um orðið kynskiptingur í pessari rannsókn. Rannsóknin mælir pó ekki hómófóbíu, bífóbíu eða transfóbíu pó pær geti endurspeglast í heterósexísku orðalagi en slíkt gæti verið efni annarra rannsókna. Einnig skoðar rannsóknin eingöngu nokkrar birtingarmyndir heterósexísks orðalags. Skilningsleysi eða ónærgætnar spurningar eins og Jón Ingvar Kjaran og Ingólfur Ásgeir Jóhannesson (2010) lýstu gætu verið önnur form heterósexísks orðalags en einnig gætu birtingarmyndirnar verið aðrar og slíkt efni í frekari rannsóknir. 


\section{Lokaorð}

Niðurstöður rannsóknarinnar gefa vísbendingar um að heterósexískt orðalag sé misalgengt eftir birtingarmyndum pess. Rúmlega helmingur pátttakenda hafði á einhverjum tímapunkti undanfarinn mánuð notað heterósexísk orð. Orðin faggi/faggalegt voru oftast notuð og pá í peirri merkingu að viðkomandi líkaði ekki tiltekin hegðun. Niðurstöðurnar benda einnig til pess að strákar séu líklegri en stelpur til að nota heterósexískt orðalag. Niðurstöðurnar gefa vísbendingar um að nemendur íslenskra framhaldsskóla séu ólíklegri til að nota heterósexískt orðalag í skólastofunni, í ípróttatíma og í búningsklefanum en utan skólans. Um eða yfir helmingur pátttakenda upplifði ópægindi af flestum formum heterósexísks orðalags. Dað sem pó vakti athygli var hve hátt hlutfall nemenda hafði notað orðið kynskiptingur um trans fólk og að pað olli pátttakendum síst ópægindum að heyra kynskiptingur og transa/tranný um trans fólk. Slíkt gæti bent til að framhaldsskólanemar geri sér síður grein fyrir neikvæðri merkingu orðanna, að minnsta kosti varðandi notkun orðsins kynskiptingur. Aftur á móti virtust peir meðvitaðri um neikvæða merkingu annars heterósexísks orðalags.

Hinsegin nemendur eru ekki peir einu sem gætu upplifað ópægindi af að heyra heterósexískt orðalag (Kosciw o.fl., 2016; Taylor o.fl., 2011) og um eða yfir helmingur pátttakenda rannsóknarinnar upplifði ópægindi í einhverjum mæli af að heyra flest form pess (eða pegar pað beindist að peim). Taylor o.fl. (2011) bentu á að gagnkynhneigðir nemendur urðu fyrir barðinu á hómófóbískum uppnefnum, peir áttu vini eða vandamenn sem voru hinsegin eða peir skömmuðust sín fyrir að hafa notað uppnefnin sem gæti möguleg skýrt ópægindin sem peir upplifðu af að heyra orðanotkunina. Einnig gætu nemendur hafa hlotið einhverja fræðslu eða menntun sem gerði pá meðvitaðri um málefni hinsegin fólks.

Mögulegt er að einhverjir framhaldsskólanemar sem nota heterósexískt orðalag sjái ekki hag sinn 1 að hætta orðanotkuninni pó peir fái fræðslu og kennslu um skaðsemi orðalagsins og málefni hinsegin fólks. Heterósexísk orðanotkun gæti pjónað peim tilgangi að áminna einstaklinginn sem orðalaginu er beint að um að tiltekin hegðun samræmist ekki viðmiðum hins gagnkynhneigða regluveldis varðandi kyngervi. Orðanotkunin getur pó einnig falist 1 a a tryggja að hegðun pess sem talar sé túlkuð innan gagnkynhneigðra viðmiða, til dæmis með notkun frasans no homo. Dví er mögulegt að einhverjir upplifi að heterósexísk orðanotkun hafi jákvæð áhrif á félagslega stöðu sína meðal samnemenda.

Niðurstöður rannsóknar Pascoe (2005) og Jóns Ingvars Kjarans (2016) gefa dæmi um hegðun eða líkama sem eru jaðarsettir með orðanotkun sem er álík heterósexískri. Í niðurstöðum rannsóknar Pascoe (2005) voru strákar uppnefndir fag til dæmis fyrir að sýna tilfinningar, gera mistök og sýna öðrum strákum of mikinn áhuga. İ niðurstöðum rannsóknar Jóns Ingvars Kjarans (2016) voru lýsingarorðin faggalegur og trukkur notuð yfir karla og konur sem fylgdu ekki kynjuðum viðmiðum um útlit. Í niðurstöðum rannsóknar Pascoe (2005) kom einnig fram að orðið gay væri notað sem samheiti fyrir heimskulegt og notað yfir til dæmis föt, kvikmyndir eða jafnvel hóp af fólki. Dví virðist í sumum tilfellum sem svo að ekki purfi mikið til að orðalagi álíkt heterósexískri orðanotkun sé beint að einstaklingum. Raunar virðist orðanotkunin samkvæmt rannsóknum Pascoe (2005) og Jóns Ingvars Kjarans (2016) pjóna peim tilgangi að jaðarsetja líkamsvöxt eða hegðun sem virðist mannleg (eins og að hafa tilfinningar, gera mistök og sýna öðru fólki (af sama kyni) áhuga) en samræmist ekki viðmiðum um kyngervi. Hafa parfí huga að rannsókn Pascoe (2005) var framkvæmd í Bandaríkjunum og fyrir tæplega 15 árum svo niðurstöðurnar gefa frekar vísbendingar um mögulega orðanotkun hérlendis en raunhæfa mynd.

Hinsegin nemendur væru ekki einir um að hagnast á pví að draga úr eða uppræta heterósexískt orðalag heldur einnig gagnkynhneigðir sískynja nemendur sem upplifa ópægindi af að heyra pað. Slíkt er í samræmi við rannsókn Taylor o.fl. (2011) sem benti jafnframt á að jákvæður skólabragur par sem margbreytileikanum er fagnað væri í hag allra nemenda, burtséð frá kynhneigð, kyngervi eða menningarlegum bakgrunni og samræmist pað Aðalnámskrá framhaldsskóla (Mennta- og menningarmálaráðuneytið, 2012). Meðal peirra pátta sem Taylor o.fl. (2011) og Kosciw o.fl. (2016) töldu að gæetu stuðlað að jákvæðum skólabrag var að skólastefnur og námskrár taka tækju 
tillit til hinsegin nemenda. Aðalnámskrá framhaldsskóla (Mennta- og menningarmálaráðuneytið, 2012) tilgreinir nú pegar kyn og kynhneigð sem pætti sem geta valdið mismunun og nemendur eigi að hljóta fræðslu um innan grunnpáttarins ,,jafnrétti“.

Aðalnámskrá framhaldsskóla (Mennta- og menningarmálaráđuneytið, 2012) bendir einnig á að meðal peirra pátta sem nemendur eiga að hljóta bjálfun í eru samskipti sem einkennast af skilningi á jafnrétti og mannréttindum viðmælandans. Heterósexísk orðanotkun framhaldsskólanemenda samræmist pví ekki Aðalnámskrá framhaldsskóla (Mennta- og menningarmálaráđuneytið, 2012). Ætla má að ef hægt er að draga úr notkun herterósexísks orðalags meðal framhaldsskólanemenda komi pað öllum nemendum til góða, bæði meðan á námi stendur og í samfélaginu.

\section{Heterosexist words used by Icelandic upper secondary school students}

The research is about heterosexist vocabulary among students in Icelandic secondary schools but the vocabulary can take different forms. Researches point to heterosexist vocabulary causing students discomfort but few Icelandic researches exist about the topic. The goal of the research was to describe a specific Icelandic form of this vocabulary. Heterosexist vocabulary in this research consists of both Icelandic words and English loanwords. The vocabulary was defined as the usage of the words faggi/ faggalegt (fag/fagish) to describe a behaviour the speaker does not like or a boy whose behaviour does not adhere to masculine norms, or the word gay to describe a behaviour or a phenomenon that is stupid or out of place. The phrase no homo to underline ones heterosexuality was also considered to be an example of this vocabulary and the words trukkalessa (dyke) and lessa (lezza) to describe a girl whose behaviour does not adhere to feminine norms. Negative words to describe someone who is trans like kynskiptingur (an old term over trans individuals that is not considered appropriate anymore) and transa/tranný (tranny) were also considered to belong to heterosexist vocabulary. The research focuses on the prevalence of heterosexist vocabulary, gender differences in usage, if participants were more or less likely to use the vocabulary in different situations inside of school, on the internet and in other places compared to outside of school and how different forms of the vocabulary affected participants. A questionnaire was used to collect data from participants who were 18 years old or older $(n=149)$ in three Icelandic secondary schools. Of the 149 participants 67 identified as male, 81 identified as female and one identified differently. The average age of participants was 19,9 years old. The schools were all located in the capital area of Iceland and had either class centered education or course-centered education. The prevalence of heterosexist vocabulary was different depending on forms. Participants were least likely to have used transa/tranný to refer to a trans individual but only $5 \%$ had used it in the past month. Participants were most likely to have used the words faggi/faggalegt to describe behaviour they did not like $54 \%$ had used it in the past month) and second most likely to use the Icelandic word kynskiptingur but 34\% of participants had used it the past month. Prevalence of other forms of heterosexist vocabulary was between $11-22 \%$. Boys were statistically more likely than girls to have used the words gay to describe a behaviour or a phenomenon they found stupid or out of place, faggi/faggalegt both to describe a behaviour the speaker did not like and a boy whose behaviour does not adhere to masculine norms, also they were more likely to have used the phrase no homo and transa/tranný. The difference in usage on other forms of heterosexist vocabulary was not statistically significant. There was a statistical difference in how likely or unlikely participants estimated the likely hood of themselves using heterosexist vocabulary in three different situation inside of school compared to outside of school. Those situations were the locker room, in gym classes and in the classroom but higher percentage of participants estimated themselves 
unlikely to use the vocabulary in these three situations compared to outside of school. The effects heterosexist vocabulary had on participants differed between forms. Fewer participants experienced discomfort from the word kynskiptingur (32\%) to imply that someone is trans than other forms of heterosexist vocabulary. Participants were most likely to experience discomfort from the words trukkalessa (65\%), gay to describe a behaviour that is considered stupid or out of place (64\%) and faggi/faggalegt to describe a boy whose behaviour does not adhere to masculine norms (63\%). Percentage of participants who felt discomfort of other forms of heterosexist vocabulary was between $45 \%-61 \%$. The results point to Icelandic secondary school students using heterosexist vocabulary but that the amount differs between forms of the vocabulary. It also points to students that hear the vocabulary experiencing discomfort. If there is a possibility to lessen the use of heterosexist vocabulary amongst Icelandic secondary school students it could benefit students both while studying and in the future.

Key words: Heterosexist vocabulary, heterosexism, homophobia, heteronormativity, gender, secondary school students.

\section{Um höfundana}

Aðalbjörg Eva Aðalsteinsdóttir (aea5@hi.is) útskrifaðist árið 2017 með M.Ed.gráđu í menntun framhaldsskólakennara frá Háskóla Íslands og hefur starfað við rannsóknarvinnu og sem aðstoðarkennari við Menntavísindasvið Háskóla Íslands. Dessi grein er byggð á megindlegum hluta meistararitgerðar hennar. Áhugasvið hennar sem rannsakanda beinist að hinsegin fræðum, kyngervi og jafnrétti.

Jón Ingvar Kjaran (jik@hi.is) er dósent við Menntavísindasvið, Deild menntunar og margbreytileika. Rannsóknir hans eru einkum á sviði kynjafræða, félagsfræði menntunar, hinseginfræða og hvers kyns margbreytileika.

\section{About the authors}

Aðalbjörg Eva Aðalsteinsdóttir (aea5@hi.is) graduated with an M.Ed. in Upper Secondary School Teaching from the University of Iceland in 2017 and has worked in research and as an assistant teacher at the Educational department of the University of Iceland. This article is based on the quantitative part of her masters thesis. Her research interests lies in queer studies, gender studies and equality.

Jón Ingvar Kjaran is associate professor at the School of Education, University of Iceland, Department of education and diversity. His researches focus on gender studies, sociology of education, queer studies and all kinds of diversities.

\section{Heimildir}

Aultman, B. (2014). Cisgender. Transgender Studies Quarterly, 1(1-2), 61-62. doi:10.1215/23289252-2399614

Bennett, K. (1992). Feminist bisexuality: A both/and option for an either/or world. Í E. Weise (ritstjóri), Closer to home: Bisexuality and feminism (bls. 205-231). Seattle: The Seal Press.

Burn, S. M. (2000). Heterosexuals' use of "fag" and "queer" to deride one another: A contributor to heterosexism and stigma. Journal of Homosexuality, 40(2), 1-11. doi:10.1300/J082v40n02_01

Butler, J. (1990). Gender trouble: Feminism and the subversion of identity. New York: Routledge.

Collier, K. L., Bos, H. M. W. og Sandfort, T. G. M. (2013). Homophobic name-calling among secondary school students and its implications for mental health. Journal of Youth and Adolescence, 42(3), 363-375. doi:10.1007/s10964-012-9823-2

Connell, R.W. (2005). Masculinities (2. útgáfa). Cambridge: Polity Press. 
Daniel,W.W. (2010). Biostatistics. Basic concepts and methodology for the health sciences (9. útgáfa). Hoboken, NJ:Wiley.

Donelson, R. og Rogers, T. (2004). Negotiating a research protocol for studying school-based gay and lesbian issues. Theory Into Practice, 43(2), 128-135. doi:10.1207/s15430421tip4302_6

Eckert, P. (1989). The whole woman: Sex and gender differences in variation. Language Variation and Change, 1(3), 245-267. doi:10.1017/S095439450000017X

Elmes, D., Kantowitz, B. H. og Roediger III, H. L. (2006). Research methods in psychology (8. útgáfa). Belmont:Thomson Wadsworth.

Gentile, D. M. (1993). Just what are sex and gender, anyway? A call for a new terminological standard. Psychological Science, 4(2), 120-122. doi:10.1111/j.1467-9280.1993.tb00472.x

Guasp, A., Statham, H., Jadva,V. og Daly, I. (2012). The school report. The experience of gay young people in Britain's schools in 2012. Sótt af https://www.stonewall.org.uk/sites/default/files/The_School_Report_2012_.pdf

Herek, G. M. (2000). The psychology of sexual prejudice. Current Directions in Psychological Science, 9(1), 19-22. doi:10.1111/1467-8721.00051

Herek, G. M. (2004). Beyond "homophobia": Thinking about sexual prejudice and stigma in the twenty-first century. Sexuality Research \& Social Policy, 1(2), 6-24. doi;10.1525/srsp.2004.1.2.6

Jackson, S. (2006). Gender, sexuality and heterosexuality. The complexity (and limits) of heteronormativity. Feminist Theory, 7(1), 105-121. doi:10.1177/1464700106061462

Jón Ingvar Kjaran. (2016). „Faggi, tappi, lessa, feit eða heit“: Orðtíðni framhaldsskólanema um staðalmyndir kynhneigðar og kyngervis. Netla - Veftímarit um uppeldi og menntun. Sótt af http://netla.hi.is/greinar/2016/ryn/09_ryn_arsrit_2016.pdf

Jón Ingvar Kjaran og Ingólfur Ásgeir Jóhannesson. (2010). „Ég myndi alltaf enda með einhverri stelpu “: Eru framhaldsskólar á Íslandi gagnkynhneigðir? Rádstefnurit Netlu - Menntakvika 2010. Sótt af http://netla.hi.is/menntakvika2010/017.pdf

Jón Ingvar Kjaran og Ingólfur Ásgeir Jóhannesson. (2011). Er rýmið í íslenskum framhaldsskólum gagnkynhneigt? Búningsklefinn, leikfimisalurinn og skólastofan. Í Ása Guðný Ásgeisdóttir, Helga Björnsdóttir og Helga Ólafsdóttir (ritstjórar), Djódarspegillinn 2011. Rannsóknir í félagsvísindum XII (bls. 332-339). Sótt af http://skemman.is/stream/ get/1946/10261/25581/3/Felagsogmannv_deild.pdf

Kosciw, J. G., Greytak, E. A., Bartkiewicz, M. J., Boesen, M. J. og Palmer, N. A. (2012). The 2011 national school climate survey: The experiences of lesbian, gay, bisexual and transgender youth in our nation's schools. Sótt af https://www.glsen.org/ sites/default/files/2011 National School Climate Survey Full Report.pdf

Kosciw, J. G., Greytak, E.A., Giga, N. M.,Villenas, C. og Danischewski, D. J. (2016). The 2015 national school climate survey: The experiences of lesbian, gay, bisexual, transgender, and queer youth in our nation's schools. Sótt af https://www.glsen.org/ sites/default/files/2015 National GLSEN 2015 National School Climate Survey \%28NSCS\%29 - Full Report_0.pdf

McHugh, M. L. (2013). The chi-square test of independence. Biochemia Medica, 23(2), 143-149. doi:10.11613/BM.2013.018

Mennta- og menningarmálaráđuneytið. (2012). Ađalnámskrá framhaldsskóla 2011:Almennur hluti (2. útgáfa). Sótt af https:// www.stjornarradid.is/verkefni/menntamal/namskrar/

Nayak, A. og Kehily, M. J. (1996). Playing it straight: Masculinities, homophobias and schooling. Journal of Gender Studies, 5(2), 211-230. doi:10.1080/09589236.1996.9960644

Nicolas, G. og Skinner, A. (2012). “That's so gay!” Priming the general negative usage of the word gay increases implicit anti-gay bias. The Journal of Social Psychology, 152(5), 654-658. doi:10.1080/00224545.2012.661803

Pascoe, C. J. (2005). 'Dude, you're a fag': Adolescent masculinity and the fag discourse. Sexualities, 8(3), 329-346. doi:10.1177/1363460705053337

Payne, E. C. (2007). Heterosexism, perfection, and popularity:Young lesbians' experiences of the high school social scene. Educational Studies, 41(1), 60-79. doi:10.1080/00131940701309054

Pharr, S. (1988). Homophobia: A weapon of sexism. Inverness: Chardon.

Renold, E. (2005). Girls, boys and junior sexualities: Exploring childrens' gender and sexual relations in the primary school. Abingdon: RoutledgeFalmer.

Rich, A. (1980). Compulsory heterosexuality and lesbian existence. Signs, 5(4), 631-660. Sótt af http://links.jstor.org/ sici?sici=0097-9740\%28198022\%295\%3A4<631\%3ACHALE >2.0.CO\%3B2-2

Sigurður Kristinsson. (2013). Siðfræði rannsókna og siðanefndir. Í Sigríður Halldórsdóttir (ritstjóri), Handbók í aðferðafreði rannsókna (bls. 71-88). Akureyri: Háskólinn á Akureyri.

Slaatten, H., Anderssen, N. og Hetland,J. (2014). Endorsement of male role norms and gay-related name-calling. Psychology of Men \& Masculinity, 15(3), 335-345. doi:10.1037/a0033734

Slaatten, H. og Gabrys, L. (2014). Gay-related name-calling as a response to the violation of gender norms. The Journal of Men's Studies, 22(1), 28-33. doi:10.3149/jms.2201.28 
Slangurorðabókin. (2011). Kærustufaggi. Í Einar Björn Magnússon og Guðlaugur Jón Árnason (ritstjórar), Slangurorđabókin. Sótt pann 30.05.2017 af http://slangur.snara.is/?p=5492

Sugano, E., Nemoto,T. og Operario, D. (2006). The impact of exposure to transphobia on HIV risk behavior in a sample of transgendered women of color in San Francisco. AIDS and Behavior, 10(2), 217-225. doi:10.1007/s10461-005-9040-z

Taylor, C., Peter,T., McMinn, T. L., Elliott,T., Beldom, S., Ferry, A., .. Schachter, K. (2011). Every class in every school:The first national climate survey on homophobia, biphobia, and transphobia in Canadian schools. Final report. Sótt af https://egale. ca/wp-content/uploads/2011/05/EgaleFinalReport-web.pdf

Trans Ísland. (e.d.-a). Orðalisti. Sótt af http://trans.samtokin78.is/upplysingar/ordalisti/

Trans Ísland. (e.d.-b). Um félagið. Sótt af http://trans.samtokin78.is/um-felagid/

Trans Ísland. (e.d.-c). Hvað er að vera trans? Sótt af http://trans.samtokin78.is/upplysingar/trans/

Warner, M. (1993). Introduction. Í M. Warner (ritstjóri), Fear of a queer planet. Queer politics and social theory (bls. vii-xxxi). Minneapolis: University of Minnesota Press.

Weber, P. og Gredig, D. (2018). Prevalence and predictors of homophobic behavior among high school students in Switzerland. Journal of Gay \& Lesbian Social Services, 30(2), 128-153. doi:10.1080/10538720.2018.1440683

Póra Björk Hjartardóttir. (2005). Baráttan um orðin. Orðanotkun tengd samkynhneigð. Íslenskt mál, 26, 83-122. Sótt af https://timarit.is/view_page_init.jsp?pageId=5414561

Aðalbjörg Eva Aðalsteinsdóttir og Jón Ingvar Kjaran (2019).

Heterósexísk orðanotkun íslenskra framhaldsskólanema.

Netla - Veftímarit um uppeldi og menntun. Menntavísindasvið Háskóla Íslands.

Sótt af http://netla.hi.is/greinar/2019/ryn/08

DOI: https://doi.org/10.24270/netla.2019.8

Slangurorðabókin liggur niðri vegna uppfærslu pegar greinin birtist. 